\title{
ANALISIS LAHAN KRITIS PADA KPHL UNIT XIV KOTA AMBON
}

\author{
CRITICAL LAND ANALYSIS IN KPHL \\ XIV UNIT AMBON CITY
}

\author{
${ }^{3}$ Zusanna F.Y. Sahupala; ${ }^{1}$ Gun Mardiatmoko; ${ }^{2}$ Agustinus Kastanya \\ Prodi Manajement Hutan, Pasca Universitas Pattimura \\ e-mail : nadeithasha@gmail.com
}

\begin{tabular}{|l|l|}
\hline Diterima : 11 Mei 2018 & Disetujui : 29 Mei 2018 \\
\hline
\end{tabular}

\begin{abstract}
Abstrak
Perambahan hutan terjadi di mana-mana ketika masih banyak pihak yang belum memahami nilai dari berbagai manfaat sumber daya hutan sehingga menimbulkan terjadinya eksploitasi sumber daya hutan secara berlebih sehingga terjadi degradasi dan deforestasi yang berdampak luas pada sistem tata air, berbagai daerah aliran sungai seperti meningkatnya pengikisan tanah yang mengakibatkan lahan-lahan yang tidak produktif/kritis, meningkatnya erosi dan sedimentasi, menurunnya keanekaragaman hayati, rusaknya berbagai habitat baik flora maupun fauna, serta terancamnya ekosistem hutan secara keseluruhan. Lahan kritis merupakan tanah yang mengalami atau dalam proses kerusakan kimia, fisik, dan biologi yang dapat mengganggu atau kehilangan fungsinya di dalam lingkungan. Kondisi ini dapat merusak tata air dan lingkungan sekitarnya. Dampak dari lahan kritis adalah penurunan tingkat kesuburan tanah, berkurangnya ketersediaan sumber air pada musim kemarau serta banjir pada musim hujan. Analisa terhadap karakteristik lahan kritis pada KPHL Unit XIV Kota Ambon sangat diperlukan sebagai acuan untuk melindungi vegetasi hutan yang ada di dalam areal hutan tersebut. Tujuan dilakukannya penelitian ini adalah untuk mengidentifikasi kondisi lahan kritis pada KPHL Unit XIV Kota Ambon. Berdasarkan hasil penelitian diperoleh pada Blok Inti memiliki lahan kritis seluas $1.221,15$ ha atau $70,74 \%$ dari luas Blok Inti dan lahan sangat kritis seluas 111,47 ha atau $1,48 \%$ dari luas Blok Inti. Sementara pada Blok Pemanfaatan memiliki lahan kritis seluas 51,37 ha atau 3,91\% dari luas Blok Pemanfaatan.
\end{abstract}

\section{Kata kunci : Lahan Kritis, Kota Ambon.}

Abstract
Forest encroachment occurs everywhere when there are still many people who do not understand the value of various benefits of forest resources, causing excessive exploitation of forest resources resulting in degradation and deforestation that have a wide impact on water systems, various watersheds such as increased erosion land which results in non-productive / critical lands, increased erosion and sedimentation, decreased biodiversity, destruction of various habitats both flora and fauna, and the threat of the overall forest ecosystem.

Critical land is land that experiences or is in the process of chemical, physical, and biological damage that can interfere with or lose its function in the environment. This condition can damage the water system and the surrounding environment. The impact of critical land is a decrease in the level of soil fertility, reduced availability of water sources in the dry season and flooding during the rainy season. Analysis of the characteristics of critical land in the KPHL of Unit XIV of Ambon City is very much needed as a reference to protect the forest vegetation in the forest area. The purpose of this study was to identify the condition of critical land in Ambon City Unit XIV KPHL. Based on the research result, the Core Block has a critical land area of $1,221.15$ ha or $70.74 \%$ and critical land area of 111.47 ha or $1.48 \%$. While in the Utilization Block has a critical land area of 51.37 ha or $3.91 \%$.

Key words : Critical Land, Ambon City.

DOI: $10.30598 / \mathrm{jhppk} / 2018.2 .2 .188$

ISSN ONLINE: 2621-8798

Page 188 


\section{PENDAHULUAN}

Hutan tropis mengandung lebih dari setengah keanekaragaman hayati dunia. Indonesia misalnya, dengan sedikit lebih dari $1 \%$ luas lahan dunia merupakan rumah bagi $10 \%$ spesies tanaman dunia, $12 \%$ mamalia, $16 \%$ reptil dan amfibi, dan $17 \%$ spesies burung. Selain itu juga berfungsi sebagai simpanan modal alam yang memberikan beragam jasa ekosistem vital yang mendukung ketahanan air, energi, pangan, dan kesehatan pada skala lokal hingga global, dan fundamental bagi kesejahteraan dan ketahanan masyarakat dan ekonomi di masa depan (Rautner, 2013).

Saat ini masih banyak pihak yang belum memahami nilai dari berbagai manfaat sumber daya hutan sehingga menimbulkan terjadinya eksploitasi sumber daya hutan yang berlebih. Pembangunan perkotaan cenderung meminimalkan ruang terbuka hijau. Lahan terbuka hijau dialihfungsikan menjadi kawasan permukiman, perdagangan, kawasan industri, jaringan transportasi, serta prasarana dan sarana perkotaan lainnya. Lingkungan perkotaan akhirnya hanya berkembang secara ekonomi, tetapi secara ekologi menurun. Degradasi sumber daya hutan telah berdampak luas pada sistem tata air, berbagai daerah aliran sungai seperti meningkatmya pengikisan tanah yang mengakibatkan lahan-lahan yang tidak produktif/kritis, meningkatnya erosi dan sedimentasi, menurunnya keanekaragaman hayati, rusaknya berbagai habitat baik flora maupun fauna, serta terancamnya ekosistem hutan secara keseluruhan. Kondisi tersebut juga menyebabkan terganggunya keseimbangan ekosistem perkotaan yang ditandai dengan meningkatnya suhu udara, pencemaran udara (meningkatnya kadar CO, ozon, karbondioksida, debu, suasana yang gersang, monoton, bising dan kotor), banjir, intrusi alir laut, kandungan logam berat tanah meningkat, dan menurunnya permukaan air tanah.

Salah satu upaya konservasi adalah dengan melakukan pemanfaatan lahan hutan secara baik. Sebagai upaya pemerintah dalam pemanfaatan hutan yang lebih berkelanjutan dan berkeadilan, maka Kementerian Kehutanan telah mencanangkan program pembentukan Kesatuan Pengelolaan Hutan di tiap Provinsi. Mengacu pada UU No. 41 Tahun 1999 
tentang Kehutanan menyebutkan terdapat 3 bentuk KPH yang didasari pada fungsi hutan, yaitu Kesatuan Pengelolaan Hutan Konservasi (KPHK) yaitu KPH pada Kawasan Hutan Konservasi, Kesatuan Pengelolaan Hutan Lindung (KPHL) yaitu KPH pada Kawasan Hutan Lindung dan Hutan Produksi di mana Hutan Lindung lebih luas serta Kesatuan Pengelolaan Hutan Produksi (KPHP) yaitu Kesatuan Pengelolaan Hutan yang arahan Pengelolaannya untuk Produksi Hasil Hutan Kayu (HHK) maupun Hasil Hutan Bukan Kayu (HHBK) dan Hutan Lindung di mana kawasan Hutan Produksi lebih luas. Selain itu terdapat PP No. 6 Tahun 2007 tentang Tata Hutan dan Penyusunan Rencana Pengelolaan Hutan serta Pemanfaatan Hutan yang bertujuan untuk mewujudkan pengelolaan hutan yang efisien dan lestari.

Pengelolaan hutan di Kota Ambon termasuk dalam Kesatuan Pengelolaan Hutan Lindung (KPHL) Kota Ambon Unit XIV, di mana wilayah kerja KPHL Kota Ambon meliputi Pulau Ambon dan Pulau-pulau Lease. Wilayah KPHL Kota Ambon terbagi atas 4 lokasi yaitu Kawasan Hutan Lindung Gunung Nona, Hutan
Lindung (BPKH Wilayah IX Ambon, 2015).

Hasil penataan blok berdasarkan kriteria telah ditetapkan sesuai dengan Peraturan Dirjen Planologi Kehutanan P.5/VII-WP3.H/2012 mengenai Tata Hutan dan Penyusunan Rencana Pengelolaan Hutan di wilayah KPHP maka kawasan KPHL Unit XIV Kota Ambon memiliki kawasan hutan sesuai fungsi yaitu Hutan Lindung yang dikelompokkan dalam 3 arahan Blok Pengelolaan yaitu :

\section{Blok Inti}

Blok Inti merupakan kawasan hutan yang berfungsi untuk perlindungan mutlak dan tidak diperkenankan adanya perubahan apapun oleh kegiatan manusia serta perubahan dan perkembangan yang terjadi berjalan secara alami tanpa campur tangan manusia, kecuali kegiatan untuk penelitian, pemantauan, perlindungan, dan pengamanan.

\section{Blok Khusus}

Blok Khusus merupakan blok yang difungsikan sebagai areal untuk menampung kepentingan-kepentingan khusus yang ada dalam wilayah KPHL Unit XIV Kota Ambon.

3. Blok Pemanfaatan 
Penetapan Blok Pemanfaatan jasa lingkungan di kawasan KPHL Unit XIV Kota Ambon didasarkan pada kenyataan bahwa sebagian besar wilayah sebagi hutan lindung yang memiliki fungsi hidroororologis terutama pengaturan tata air.

Perubahan kondisi hutan akibat deforestasi dan degradasi tidak terlepas dari peranan manusia dan lingkungan yang mempengaruhinnya. Hasil studi yang dilakukan oleh CIFOR melaporkan tentang berbagai penyebab meningkatnya laju deforestasi di Indonesia adalah sebagai akibat terjadinya ekonomi krisis di tahun 1997 selain itu terkait juga dengan reformasi politik dan desentralisasi urusan kehutanan yang mengakibatkan hutan di Indonesia semakin terfragmentasi dan rentan terhadap kebakaran (Forest Watch Indonesia, 2001). Salah satu cara untuk mengatasi masalah deforestasi dan degradasi adalah dengan konservasi. Menurut Groom, dkk., (2006) upaya penyelamatan suatu lahan kritis tidak cukup hanya dengan mengelola sebuah populasi tapi juga harus memperhatikan lanskap di mana populasi itu bergerak atau beraktifitas. Oleh karena itu upaya konservasi yang dilakukan harus dalam skala lanskap. Banyak kawasan konservasi yang terisolasi satu sama lain karena berada di antara kawasan pemanfaatan oleh manusia. Kawasan konservasi yang terfragmen satu sama lain harus dihubungkan dalam bentuk jaringan lanskap.

Pulau Ambon adalah sebuah pulau kecil dengan luas $958.83 \mathrm{Km}^{2}$. Pulau Ambon memiliki tingkat kepekaan lingkungan yang sangat tinggi terutama terhadap perubahan-perubahan fisik yang terjadi di permukaan pulau sehingga minimal pulau ini harus dapat mencadangkan $50 \%$ wilayahnya untuk kepentingan konservasi hutan karena vegetasi hutan adalah satu-satunya komponen biotik yang dapat menjaga tingkat kepekaan tersebut (BPKH Wilayah IX Ambon, 2015).

Sehubungan dengan hal ini maka diperlukan analisa karakteristik lanskap pada areal-areal KPHL Unit XIV Kota Ambon. Pengetahuan tentang karakteristik lanskap sangat penting untuk menentukan kebijakan sistem perencanaan dan pengelolaan lanskap hutan yang lestari pada suatu wilayah. Dengan demikian analisis terhadap lahan kritis pada KPHL Unit XIV Kota Ambon sangat diperlukan sebagai acuan untuk melindungi vegetasi hutan yang ada di dalam areal hutan tersebut. Tujuan dilakukannya penelitian ini adalah untuk mengidentifikasi kondisi lahan kritis pada KPHL Unit XIV Kota Ambon. 


\section{METODE PENELITIAN}

Penelitian dilaksanakan pada wilayah KPHL Unit XIV Kota Ambon. Secara geografis KPHL Unit XIV Kota Ambon terletak antara $132^{\circ} 25^{\prime} 05^{\prime \prime}$ s.d. $133^{\circ} 01^{\prime} 45^{\prime \prime}$ Bujur Timur dan 5'32'43”, s.d. 603'25" Lintang Selatan. Lokasi KPHL Unit XIV Kota Ambon di Pulau
Ambon, berada pada beberapa kecamatan yaitu Kecamatan Teluk Ambon, Kecamatan Baguala, Kecamatan Leitimur, Kecamatan Sirimau, dan Kecamatan Nusaniwe, Kota Ambon, Provinsi Maluku. Karakteristik lanskap hutan dianalisa dengan analisa spasial.

\section{HASIL DAN PEMBAHASAN}

Kondisi kekritisan lahan pada wilayah KPHL Unit XIV Kota Ambon dapat dilihat pada Gambar 1:

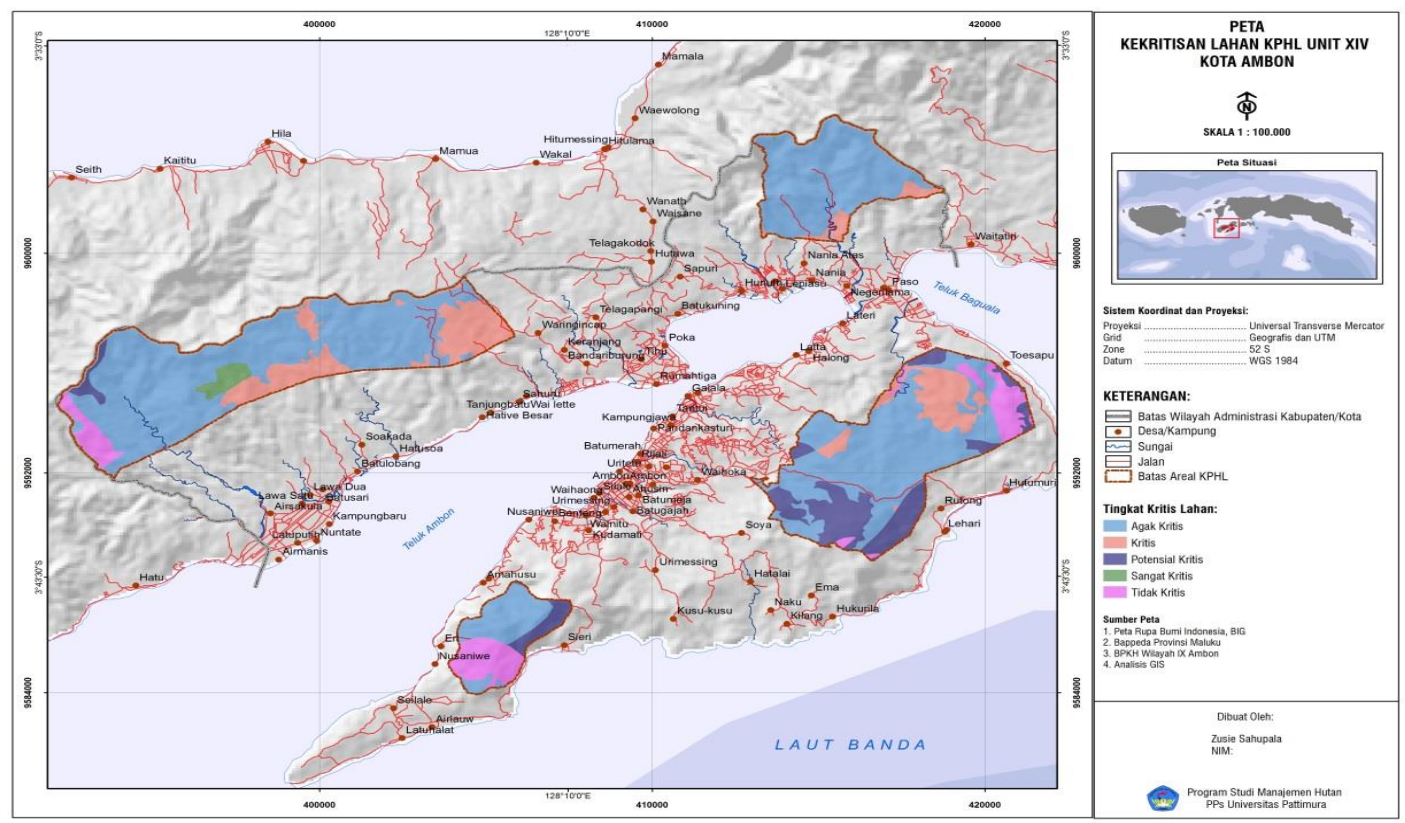

Sumber : Data spasial yang diolah, Tahun 2018.

Gambar 1. Kekritisan Lahan KPHL Unit XIV Kota Ambon.

KPHL Unit XIV Kota Ambon merupakan kawasan dengan fungsi lindung yang memiliki luas 9.495,16 ha yang terbagi dalam 3 blok yaitu Blok
Inti, Blok Khusus, dan Blok Pemanfaatan. Setelah dilakukan analisa spasial maka diperoleh kondisi 
kekritisan lahan seperti yang terdapat

pada Tabel 1:

Tabel 1. K ondisi Lahan Kritis Pada Wilayah KPHL Unit XIV Kota Ambon.

\begin{tabular}{|l|c|c|}
\hline Kondisi Blok & Luas (ha) & \% \\
\hline Blok Inti & & 70.47 \\
\hline Agak Kritis & $5,313.14$ & 16.20 \\
\hline Kritis & $1,221.15$ & 4.44 \\
\hline Potensial Kritis & 334.55 & 1.48 \\
\hline Sangat Kritis & 111.47 & 7.42 \\
\hline Tidak Kritis & 559.29 & $\mathbf{1 0 0}$ \\
\hline Total & $\mathbf{7 , 5 3 9 . 6 0}$ & 36.81 \\
\hline Blok Khusus & & 43.17 \\
\hline Agak Kritis & 235.84 & 20.02 \\
\hline Potensial Kritis & 276.55 & 100 \\
\hline Tidak Kritis & 128.27 & \\
\hline Total & $\mathbf{6 4 0 . 6 7}$ & 70.21 \\
\hline Blok Pemanfaatan & & 3.91 \\
\hline Agak Kritis & 923.17 & 25.17 \\
\hline Kritis & 51.37 & 0.71 \\
\hline Potensial Kritis & 330.97 & 100 \\
\hline Tidak Kritis & 9.39 & \\
\hline Total & $\mathbf{1 , 3 1 4 . 9 0}$ & \\
\hline Grand Total & $\mathbf{9 , 4 9 5 . 1 6}$ & \\
\hline
\end{tabular}

Sumber : Data spasial yang diolah, Tahun 2018.

Pada Tabel 1 terlihat bahwa pada Blok Inti dan Blok Pemanfaatan terdapat lahan kritis. Blok Inti memiliki lahan kritis seluas $1.221,15$ ha atau $70,74 \%$ dari luas Blok Inti dan lahan sangat kritis seluas 111,47 ha atau 1,48 $\%$ dari luas Blok Inti. Sesuai dengan fungsi Blok Inti untuk perlindungan maka keadaan ini harus segera ditangani. Sementara pada Blok Pemanfaatan memiliki lahan kritis seluas 51,37 ha atau $3,91 \%$ dari luas Blok Pemanfaatan. Menurut Muljadi dan Soepraptohardjo (1975) lahan kritis adalah lahan yang karena tidak sesuai dengan penggunaan dan kemampuannya telah mengalami atau dalam proses kerusakan fisik, kimia, dan biologi yang pada akhirnya membahayakan fungsi hidrologis, orologis, produksi pertanian, permukiman, dan kehidupan sosial ekonomi dari daerah lingkungan yang mempengaruhinya. Erosi akibat hujan mengakibatkan tanah-tanah terkikis dan tidak produktif lagi sebagai lahan 
pertanian. Pembukaan lahan pertanian baru, daerah pemukiman, maupun aktifitas pembangunan lainnya mengakibatkan berkurangnya wilayah hutan yang berfungsi sebagai penahan erosi. Hal ini sesuai dengan apa yang dikemukakan oleh Muljadi dan Soepraptohardjo (1975) bahwa lahan kritis umumnya terjadi karena erosi

\section{KESIMPULAN}

Berdasarkan hasil penelitian maka diperoleh kesimpulan yaitu wilayah KPHL Unit XIV Kota Ambon

\section{DAFTAR PUSTAKA}

Balai Pemantapan Kawasan Hutan (BPKH) Wilayah IX Ambon, 2015. Rencana Pengelolaan Hutan Jangka Panjang KPHL Unit XIV Kota Ambon 20162025.

Kartodihardjo, H., Nugroho, B., Putro, H. R., 2011. Pembangunan Kesatuan Pengelolaan Hutan. yang dipercepat (accelerated) oleh aktifitas manusia Jika hal ini tidak ditangani dengan baik maka dalam beberapa tahun ke depan wilayah Kota Ambon akan mengalami degradasi yang sangat parah. Ini menunjukkan bahwa perlu dilakukan rehabilitasi lahan pada areal KHPL Unit XIV Kota Ambon.

merupakan kawasan dengan fungsi lindung seluas 9.495,16 ha yang didominasi oleh hutan lahan kering sekunder seluas 4.905,90 atau 51,67\% dari luas wilayah.

Konsep, Peraturan Perundangan, dan Implementasi.

Muljadi, D. dan Soepraptohardjo, 1975. Masalah Data Luas dan Penyebaran Tanah-Tanah Kritis. Simposium Pencegahan dan Pemulihan Tanah Kritis Dalam Rangka Pengembangan Wilayah. Jakarta.

Rautner, M., 2013. The Little Book of Big Deforestation Drivers Global Canopy Programme. 
